\title{
Photocatalytic treatment of volatile organic compounds emitted from mosquito repel incense burning
}

\author{
Nguyen Nhat Huy ${ }^{1,2}{ }^{*}$, Nguyen Thi Bich Ha ${ }^{1,2}$, Dinh Pham Ngoc Huyen ${ }^{1,2}$, Vo Thi Thanh Thuy ${ }^{1,2}$, \\ Hoang Cong Anh Duy ${ }^{1,2}$, Lam Pham Thanh Hien ${ }^{1,2}$, Nguyen Thi Thuy ${ }^{3}$
}

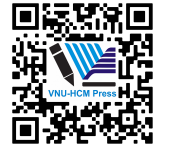

Use your smartphone to scan this QR code and download this article

${ }^{1}$ Faculty of Environment and Natural Resource, Ho Chi Minh City University of Technology (HCMUT)

${ }^{2}$ Vietnam National University Ho Chi Minh City

${ }^{3}$ Faculty of Environment - Natural Resources and Climate Change, Ho Chi Minh City University of Food Industry

Correspondence

Nguyen Nhat Huy, Faculty of

Environment and Natural Resource, Ho Chi Minh City University of Technology (HCMUT)

Vietnam National University Ho Chi Minh City

Email: nnhuy@hcmut.edu.vn

\section{History}

- Received: 29/08/2019

- Accepted: 14/04/2020

- Published: 30/06/2020

DOI : 10.32508/stdjsee.v4i1.509

\section{Check for updates}

\section{Copyright}

(c) VNU-HCM Press. This is an openaccess article distributed under the terms of the Creative Commons Attribution 4.0 International license.

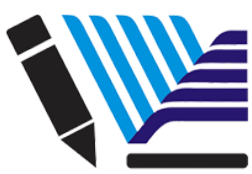

VNU-HCM Press

\begin{abstract}
Mosquito-repellent incense (MRI) is a widely used product in the household. Although the quality of MRI has been strictly managed, it still has certain health effects in practical use. This study investigated the level of volatile organic compounds (VOCs) in MRI smoke and its removal ability by photocatalysis. An online survey was conducted using Google form to select three typical types of MRI which are the most popular use in Vietnam (i.e., MOSFLY, RAID, and JUMBO VAPE) as well as their use level and condition. These types of MRIs were then burnt in a normal room for $8 \mathrm{~h}$ to determine the level of air pollution emission. Results from room test show that the tVOCs concentration emitted from one of the MRIs was as high as $1621 \mathrm{ppb}$, which was the highest pollution level among the three MRIs tested. This type of MRI was then employed as VOCs pollutant source for testing the treatment ability of a photocatalytic equipment in a closed chamber. The experimental treatment of emitted VOCs by the photocatalytic treatment equipment showed that titania nanotubes (TNTs) modified with metal salt and heat treatment achieved high removal efficiency. It has reached indoor air standards of $\leq 490 \mathrm{ppb}$ after 180 min of treatment with an input concentration of about $1,600 \mathrm{ppb}$. By changing the conditions of TNTs modification and operation conditions, the highest treatment efficiency was achieved with $2 \mathrm{~g}$ of zinc doped TNTs at a Zn/Ti molar ratio of 0.5\%, calcined at $500^{\circ} \mathrm{C}$, in which the treatment to meet the standard reached the shortest treatment time. The results in this study indicate that burning MRI could cause indoor air pollution that may affect human health and photocatalysis is a potential technology for treating VOCs from indoor MRI burning.

Key words: Mosquito-repellent incense, VOCs, indoor air pollution, photocatalysis
\end{abstract}

\section{INTRODUCTION}

One of the most popular methods of repelling mosquitoes is to use incense. Mosquito-repellent incense (MRI) or mosquito coil with spiral-shaped contains compounds that repel mosquitoes derived from dried daisies. According to Strickman et al. (2009), components of MRI may include pyrethrum, pyrethrins, allethrin, esbiothrin, butylated hydroxytoluene, piperonyl butoxide, and n-octyl bicycloheptene dicarboximide ${ }^{1}$. With high mosquito repellent effect at low cost, MRI is widely used, especially in Asia, Africa, South America, and Australia ${ }^{2}$. In Vietnam, the use of mosquito-repellent incense at home is very popular, especially in rural areas.

Although it is considered as a safe product for health, MRI smoke contains some air pollutants such as fine dust, formaldehyde ${ }^{2}$, and polycyclic aromatic hydrocarbons (PAHs) ${ }^{3}$. This smoke can irritate some parts of the body ${ }^{2}$ and affect the lungs in adolescents and infants significantly ${ }^{4}$. The research of Salvi et al. (2016) indicated that the concentrations of PM2.5 and
CO by MRI burning were much higher than those by indoor cooking activities using biomass fuels ${ }^{5,6}$. However, there is a lack of information on air pollution from MRI burning in Vietnam as well as an effective solution for its smoke control.

In recent years, the photolysis under the presence of a catalytic material has been extensively studied because of its superior properties. In the field of environment, photocatalysis is particularly effective in the treatment of pollutants in low concentrations such as nitrogen oxides ${ }^{7}$, volatile organic compounds (VOCs) ${ }^{8,9}$, sulfur dioxide ${ }^{10}$, odor ${ }^{11}$, and airborne microorganisms ${ }^{12}$. Titanium dioxide $\left(\mathrm{TiO}_{2}\right)$ is usually the photocatalytic material of choice because of its appropriate oxidation and reduction potentials, high stability, and suitable band gap energy. Moreover, $\mathrm{TiO}_{2}$ is chemically stable, environmentalfriendly, relatively cheap, and easily found in the market. Among different types of $\mathrm{TiO}_{2}$, titania nanotubes (TNTs) is recently becoming an efficient and popularly used type because of its high activity and good properties $^{13-15}$. 
In this study, we conducted an online survey to select three types of mosquito-repellent incense which are the most popular use in Vietnam. The concentration of pollutants in MRI smoke was monitored in an actual room and in closed chambers. Photocatalysis was applied to treat the smoke using TNTs. Input and output VOCs concentrations were recorded and the treatment efficiency of the photocatalytic equipment at different experimental conditions was determined.

\section{MATERIALS AND METHODS}

Google form tool was used to set up an online survey form of the situation on MRI use in households and the data from surveyors were collected via Google account. The majority of respondents were students in different places, but they are currently studying and living in Ho Chi Minh City. This survey was conducted to find out the most popular MRIs used in the daily life of Vietnamese people as well as the level of use, which were then selected for testing the pollution level during the burning process.

The actual pollutant level of MRI burning in the confined space was determined in a room with a dimension of $2.8 \times 1.8 \times 3.0 \mathrm{~m}$, which has a main door with $2.3 \mathrm{~m}$ height and $0.7 \mathrm{~m}$ width and two small windows with a size of $0.6 \times 0.6 \mathrm{~m}$. The room test duration lasted for $8 \mathrm{~h}$, starting from the beginning of burning one slice of MRI, which was placed on the floor of the room. A digital measuring device was placed in the room in a position of $1.5 \mathrm{~m}$ high from the floor and data was recorded every $10 \mathrm{~min}$, as exhibited in Figure 1.

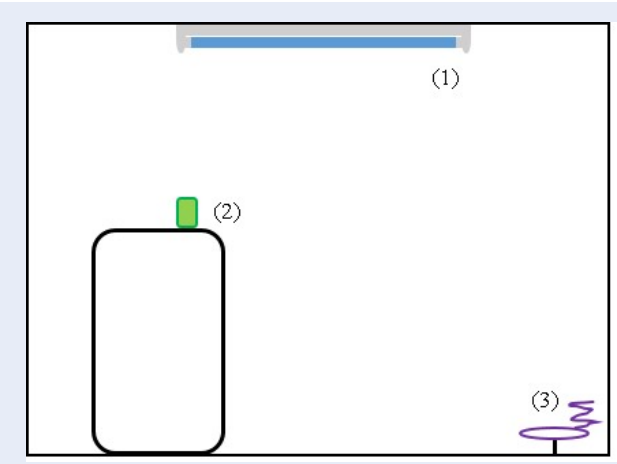

Figure 1: Room test for MRI burning: (1) fluorescence light, (2) measuring device placed on the table, and (3) MRI coil.

The chamber test for pollution level and treatment was conducted using two parallel closed chambers with a size of $850 \times 600 \times 800 \mathrm{~mm}$, as displayed in Figure 2 . A fan and a lamp were placed inside the chamber

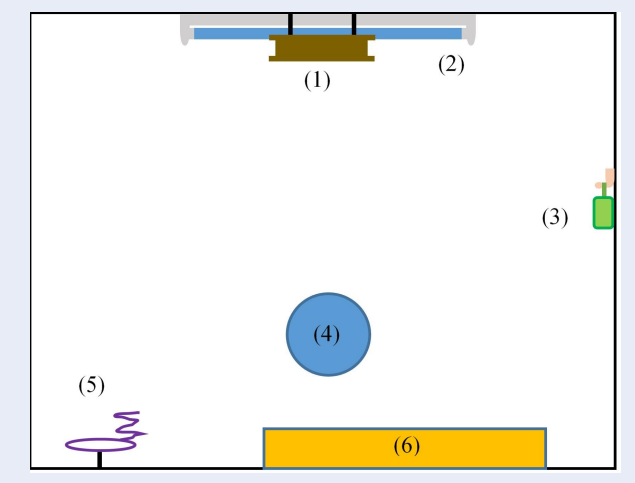

Figure 2: Chamber test for MRI burning: (1) fan, (2) light, (3) measuring device, (4) door, (5) MRI coil, and (6) treatment equipment.

to ensure that the air is circulated evenly and simulate the actual room condition. The experiments were conducted with two closed chambers, one of which contained treatment equipment (Chamber 2, treatment chamber) and the other as a control chamber without any treatment (Chamber 1). Pollutant concentrations (tVOCs) were measured in both chambers for comparison. In treatment tests, the MRI coils were burnt in both chambers until the tVOCs concentration reached around 1,600 ppb. The coils were then extinguished and the treatment equipment in Chamber 2 was turned on. The performance of the treatment equipment was calculated using the following equation:

$$
H(\%)=\frac{C_{1}-C_{2}}{C_{1}} \times 100
$$

Where: $C_{1}$ and $C_{2}$ are tVOCs concentrations in Chamber 1 and 2, respectively.

The treatment equipment is illustrated in Figure 3, which has many components. The fan (2) mounted at the top of the equipment has an effect of circulating the polluted airflow in the closed chamber through the equipment with an appropriate flow. The UVA lamp system (5) and electronic ballast (9) has the effect of generating UV light irradiating on the catalyst coated glass fiber (4) to perform the photocatalytic treatment. The air after being processed by the photocatalytic will pass through the coarse fabric filter (7) to collect dust in the air. All the above components are fixed to a cylindrical stainless steel tube (8) by racks $(1,3$, and 6$)$. The equipment length and diameter are $400 \mathrm{~mm}$ and $49 \mathrm{~mm}$, respectively.

The catalytic materials used in this study were TNTs made from $\mathrm{TiO}_{2}$ by the hydrothermal method ${ }^{16}$. The pure TNTs material was 


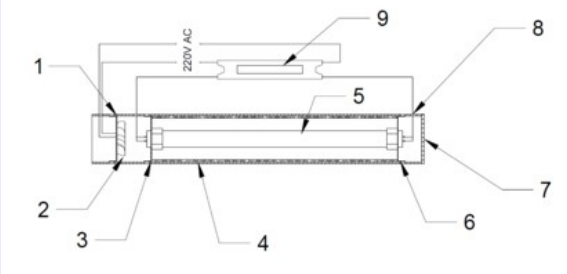

Figure 3: Photocatalytic treatment equipment: (1) fan rack, (2) fan, $(3,6)$ holder of UV-A light, (4) glass fiber plate, (5) UVA light, (7) raw filter, (8) stainless steel pipe, (9) ballast.

then modified by impregnation with metal nitrate salt precursors $\left(\mathrm{Zn}\left(\mathrm{NO}_{3}\right)_{2} \cdot 6 \mathrm{H}_{2} \mathrm{O}\right.$, $\mathrm{Al}\left(\mathrm{NO}_{3}\right)_{2} \cdot 9 \mathrm{H}_{2} \mathrm{O}, \mathrm{Fe}\left(\mathrm{NO}_{3}\right)_{3} \cdot 9 \mathrm{H}_{2} \mathrm{O}, \mathrm{Cu}\left(\mathrm{NO}_{3}\right)_{2} \cdot 3 \mathrm{H}_{2} \mathrm{O}$, $\mathrm{Cd}\left(\mathrm{NO}_{3}\right)_{2} .4 \mathrm{H}_{2} \mathrm{O}, \quad \mathrm{Co}\left(\mathrm{NO}_{3}\right)_{2} \cdot 6 \mathrm{H}_{2} \mathrm{O} \quad$ and $\left.\mathrm{Sr}\left(\mathrm{NO}_{3}\right)_{2} \cdot 6 \mathrm{H}_{2} \mathrm{O}\right)$ and calcined at different temperatures according to the procedure published in our previous works ${ }^{16,17}$. Finally, they were loaded onto glass fiber support material and placed on the inside wall of the stainless steel tube. The coating process included (i) dispersion of the desired amount of catalyst in $20 \mathrm{~mL}$ of distilled water, (ii) ultrasound treatment for $20 \mathrm{~min}$ to form a stable suspension, (iii) spreading the catalytic suspension evenly on the glass fiber sheet, and (iv) drying the coated fiber at 105 ${ }^{o} \mathrm{C}$ for $20 \mathrm{~min}$ before assembling into the treatment equipment.

All chemicals used in this study are lab-grade and originated from China. The concentration of volatile organic compounds (tVOCs) was measured by a commercial online air quality monitor (Mobile Nose, Addwii, Taiwan). This commercial measuring device was then sent for calibration at Nanoparticle and Air Quality Laboratory (Institute of Environmental Engineering, National Chiao Tung University, Taiwan) before using it in this study. The calibrated accurate range of the device with an error within \pm 1 unit is 0 $-60,000 \mathrm{ppb}$ for tVOCs.

\section{RESULTS AND DISCUSSION}

The situation of using mosquito-repellent incense in households

In order to know the most popular type of MRI used in the household and the amount of MRI coil used, a survey was conducted with the participation of 114 people (mostly in the range of $18-24$ years old). Results showed that MOSFLY, RAID, and JUMBO VAPE were the most commonly used MRI brands in Vietnam, which then denoted as A, B, and C for further investigation (not respectively, for removing the identity of the brands). The incense was often used in the evening and it was often placed in the living room (53.3\%), bedroom, and study place (31.6\%). The need to use mosquito coil increased during the rainy season due to the huge number of mosquitoes. The number of MRI used ranged from 1 to 2 slice/room/day and its use is often lower in urban areas than in rural areas. Among the surveyed people, $72 \%$ knew the health effects of MRI smoke. Although many brands of MRIs recommended that only one incense slice should be burnt for a room with an area of $35 \mathrm{~m}^{2}$ and the incense should be used in a well-ventilated area, there are still many cases of abuse of MRI use in the room without ventilation. From the surveyed results, three types of MRI were selected for further investigation with the main components presented in Table 1.

Determination of air pollution level from MRI burning in an actual room and closed chambers

Three types of MRI (i.e., A, B, and C) were applied for room experiments to determine the air pollution caused by their smoke. Data were recorded every $10 \mathrm{~min}$ and continuously for $8 \mathrm{~h}$. Results in Figure 4 show that the smoke of all three MRI types contains VOCs, which is similar to the study of Liu et al. $(2003)^{2}$. In general, the concentration of pollutants of each type varied during the test period, which unstably increased at the beginning, and then decreased at the end of the experiment. Regarding organic pollutants of one slice burning, tVOCs of MRI B reached the highest average value up to $1621 \mathrm{ppb}$, exceeding Chinese indoor air standards of $490 \mathrm{ppb}^{18}$, followed by MRI C and MRI A. MRI B was then chosen as the target incense for further experiments. Besides, the concentration of tVOCs when burning 2 slices tends to be higher than that with 1 slice, in which the highest tVOCs concentration when burning 2 slices were 1.27 times higher than that from 1 slice.

The experiment was then conducted to investigate the pollution of MRI smoke in a closed chamber with a volume of $408 \mathrm{~L}$. Due to the very high concentration of air pollutants that exceeds the upper limit of the measuring device when burning 1 slice of MRI in the closed chambers, the experiments were consequently conducted with $1 \mathrm{~cm}$ of MRI B and data were recorded every $10 \mathrm{~min}$ for $3 \mathrm{~h}$. As seen in Figure 5, the concentration of tVOCs varied from 1200 to $3000 \mathrm{ppb}$. These significantly high concentrations can be explained by the accumulation of pollutants in the limited space of the closed chamber, resulting in much higher concentrations than in the actual room. The concentration of 


\begin{tabular}{ll}
\hline Table 1: NAMES AND MAIN INGREDIENTS OF THE SELECTED TYPES \\
\hline Denoted name & Main ingredients \\
\hline A & Meperfluthrin $0.035 \%$, additive $99.965 \%$ \\
B & Meperfluthrin $0.022 \%$, additive $99.978 \%$ \\
C & Metofluthrin $0.0097 \%$, coconut powder, wood flour, wheat flour, joss powder, color, preser- \\
& vative \\
\hline
\end{tabular}

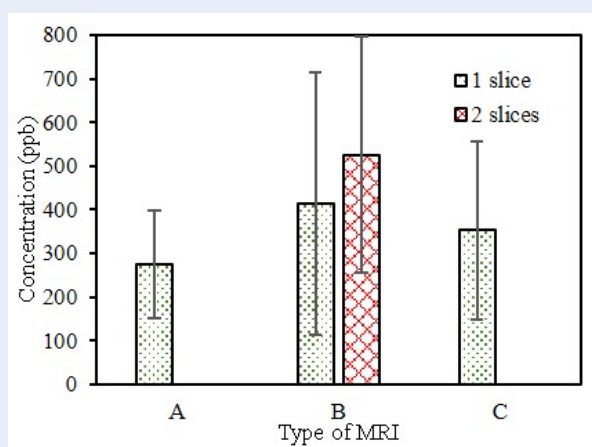

Figure 4: Average concentrations of tVOCs by 3 types of MRI (1 slice) and MRI B ( 2 slices) in $8 \mathrm{~h}$ of room test.

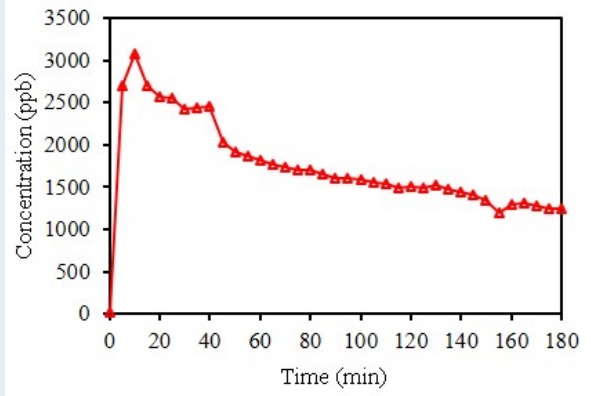

Figure 5: Concentrationsof $\mathrm{t}$ VOCs when burning $1 \mathrm{~cm}$ of MRI B in closed chambers.

tVOCs then began to decrease after 30 min when the MRI was completely burnt and decreased steadily after that throughout the test period.

\section{Experimental treatment of VOCs using pho- tocatalytic equipment}

In this study, the initial level of tVOCs in the chamber was created at around 1,600 ppb by burning MRI B. The concentration of around 1,600 ppb was chosen since 1,621 ppb was recorded as the highest concentration during the room test. Two closed chambers were used simultaneously, in which one contains the photocatalytic treatment equipment while the other is the control chamber or blank test (i.e. without the equipment). The tVOCs concentration is recorded and compared with the Chinese standard (i.e. $\leq 490$ $\left.\mathrm{ppb}^{18}\right)$.

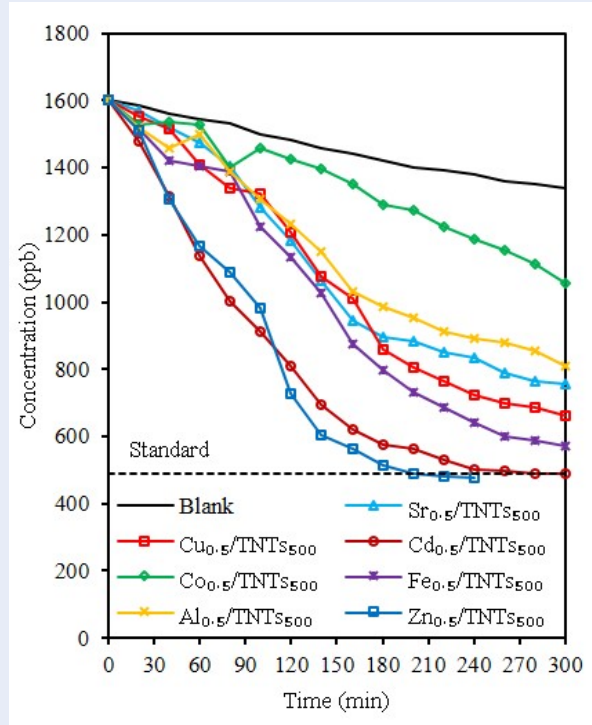

Figure 6: The concentration change of tVOCs under treatment with different metal-doped TNTs.

The experiment was first conducted to investigate the influence of metal doping (e.g, $\mathrm{Al}, \mathrm{Co}, \mathrm{Cu}, \mathrm{Zn}, \mathrm{Fe}$, $\mathrm{Cd}$, and $\mathrm{Sr}$ ) on the activity of TNTs and to find out the suitable photocatalyst for VOCs removal. The results are displayed in Figure 6 for the metal/Ti molar ratio of $0.5 \%$ and the catalyst amount of $1 \mathrm{~g}$. Although the concentration of tVOCs in both chambers decreased during $300 \mathrm{~min}$ of the experiment, the decrease rate was much faster in the chamber with the treatment equipment than in the blank one, indicating the effectiveness of photocatalytic treatment. The two photocatalysts of $\mathrm{Zn}_{0.5} / \mathrm{TNTs}_{500}$ and $\mathrm{Cd}_{0.5} / \mathrm{TNTs}_{500}$ gave the fastest treatment rates and their tVOCs concentrations reached the standard concentration after $200 \mathrm{~min}\left(\mathrm{Zn}_{0.5} / \mathrm{TNTs}_{500}\right)$ and $280 \mathrm{~min}\left(\mathrm{Cd}_{0.5} / \mathrm{TNTs}_{500}\right)$ of treatment. The other five catalysts of $\mathrm{Al}_{0.5} / \mathrm{TNTs}_{500}, \mathrm{Fe}_{0.5} / \mathrm{TNTs}_{500}$, 
$\mathrm{Co}_{0.5} / \mathrm{TNTs}_{500}, \mathrm{Sr}_{0.5} / \mathrm{TNTs}_{500}$, and $\mathrm{Cu}_{0.5} / \mathrm{TNTs}_{500}$ appeared not to be the suitable catalysts since their treated tVOCs concentrations did not reach the standard even after $300 \mathrm{~min}$ of the experiment. In terms of average treatment efficiency during $300 \mathrm{~min}$ of the experiment, $\mathrm{Zn}_{0.5} / \mathrm{TNTs}_{500}$ and $\mathrm{Cd}_{0.5} / \mathrm{TNTs}_{500}$ had similar efficiencies of $70.1 \%$ and $69.5 \%$, respectively. However, TNTs impregnated with $\mathrm{Zn}\left(\mathrm{NO}_{3}\right)_{2} \cdot 6 \mathrm{H}_{2} \mathrm{O}$ was preferred for using in further experiments because of its shorter treatment time to reach the standard of tVOCs.

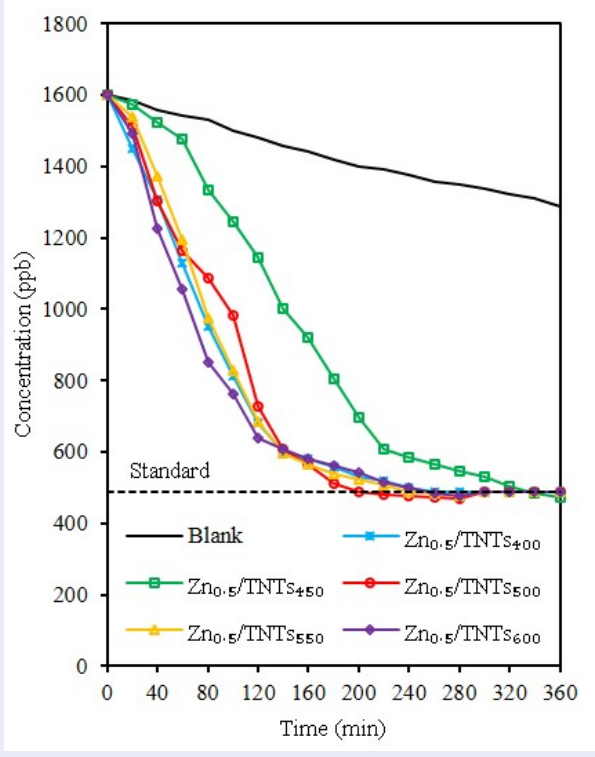

Figure 7: The concentration change of tVOCs under treatment with Zn/TNTs annealed at different temperatures.

Heat treatment or annealing is considered as an effective method for improving the crystallinity and activity of TNTs material ${ }^{19,20}$. In this study, the effect of annealing was investigated in a range of $400-600$ ${ }^{o} \mathrm{C}$ using TNTs impregnated with $\mathrm{Zn}\left(\mathrm{NO}_{3}\right)_{2} \cdot 6 \mathrm{H}_{2} \mathrm{O}$. Figure 7 depicts the effect of calcination temperature on the activity of $\mathrm{Zn} / \mathrm{TNT}$ s photocatalyst with a $\mathrm{Zn} / \mathrm{Ti}$ molar ratio of $0.5 \%$ and a catalyst amount of 1 g. When using catalyst heated at $600^{\circ} \mathrm{C}$, the concentration of tVOCs in the treatment chamber decreased faster than other catalysts during the beginning of the test from $20 \mathrm{~min}$ to $140 \mathrm{~min}$. The concentration was then slowly decreased and the standard reached after $260 \mathrm{~min}$. Meanwhile, tVOCs treated by the catalyst calcined at 500 and $550{ }^{\circ} \mathrm{C}$ reached the standard after 200 and $240 \mathrm{~min}$, respectively. For catalysts annealed at low temperatures of 400 and $450^{\circ} \mathrm{C}$, it took longer times to reach the standard. Thus, the catalyst annealed at a temperature of $500^{\circ} \mathrm{C}$ had outstanding treatment ability and was selected for further experiments.

The ratio of metal and titanium may also have an effect on the activity of the photocatalyst. In this experiment, different $\mathrm{Zn} / \mathrm{Ti}$ molar ratios of $0.5 \%, 1 \%$, and $1.5 \%$ were tested for catalyst calcined at $500{ }^{\circ} \mathrm{C}$ and catalyst amount of $1 \mathrm{~g}$ and the results are exhibited in Figure 8. Among the tested materials, the catalyst with a $\mathrm{Zn} / \mathrm{Ti}$ ratio of $0.5 \%$ gave the shortest treatment time of $220 \mathrm{~min}$. At higher ratios of $1 \%$ and $1.5 \%$, the results were not much different, in which the times to reach the standard were 300 and $320 \mathrm{~min}$, respectively.

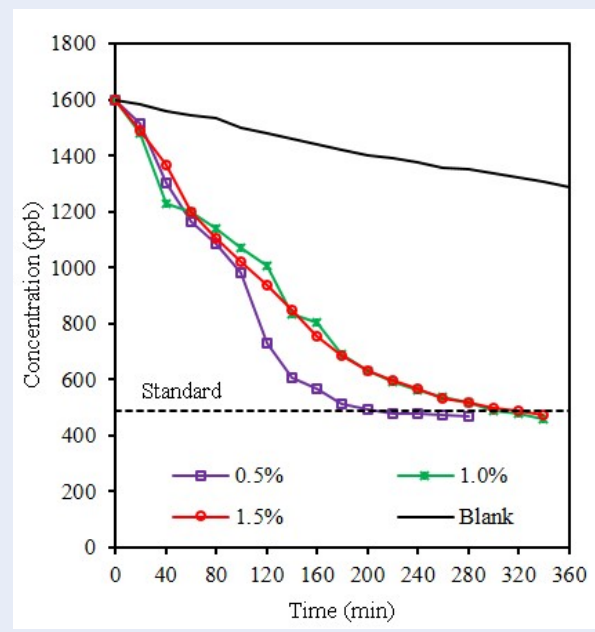

Figure 8: The concentration change of tVOCs under treatment with $\mathrm{Zn} / \mathrm{TNTs}$ at different $\mathrm{Zn} / \mathrm{Ti}$ ratios.

The suitable amount of catalyst used is also an important consideration for photocatalytic treatment application, where too much catalyst is costly but too less catalyst affects the photocatalytic activity. In this experiment, the amount of catalyst was varied in the range of $0.5-2.0 \mathrm{~g}$, and the results are displayed in Figure 9. In general, the more catalyst used, the shorter times to reach the standard were. It took only 180 min for tVOCs concentration to decrease to below the standard when using $2.0 \mathrm{~g}$ of catalyst while the use of $0.5-1.5 \mathrm{~g}$ of catalyst needed around 220 $240 \mathrm{~min}$. After $180 \mathrm{~min}$, the experiment using $2 \mathrm{~g}$ of catalyst achieved the highest efficiency of $70.6 \%$ while the lowest efficiency of $65.9 \%$ was in the case of $1.5 \mathrm{~g}$. The efficiency when using $0.5 \mathrm{~g}$ and $1 \mathrm{~g}$ was not much different. Thus, under the condition of this study, the amount of catalyst suitable for the treatment equipment is $2 \mathrm{~g}$. 


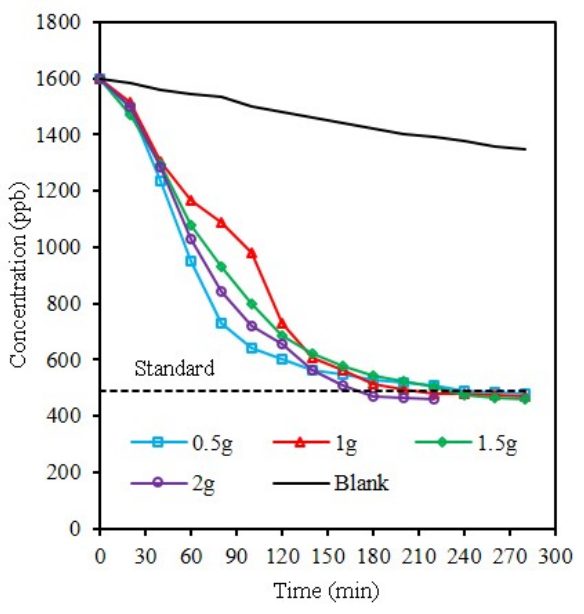

Figure 9: The concentration change of tVOCs under treatment with different catalyst amounts.

\section{CONCLUSION}

The pollution levels of VOCs were investigated when burning three types of most popular mosquitorepellent incense used in households. Room test for $8 \mathrm{~h}$ of MRI burning found that the average levels of VOCs could reach to $414 \mathrm{ppb}$ for burning 1 slice of MRI in a $15-\mathrm{m}^{3}$ room, which slightly increased to 526 ppb when burning 2 slices. In the closed chamber test for 30 min of burning MRI, the photocatalytic treatment equipment can effectively remove tVOCs and the best treatment condition was achieved when using $2 \mathrm{~g}$ of $\mathrm{Zn}$-doped TNTs at $\mathrm{Ti} / \mathrm{Zn}$ ratio of $0.5 \%$ and calcined at $500{ }^{\circ} \mathrm{C}$. Under this suitable condition, the tVOCs treatment efficiency reached $70.6 \%$ after 180 min of treatment. Future works may focus on detailed components of tVOCs and their individual removal for a better understanding of its emission and treatment.

\section{ACKNOWLEDGEMENT}

This research is funded by Ho Chi Minh City University of Technology - VNU-HCM under grant number To-MTTN-2018-09.

\section{ABBREVIATION}

MRI: Mosquito-repellent incense

PAHs: polycyclic aromatic hydrocarbons

PM2.5: particulate matter with size $\leq 2.5 \mu \mathrm{m}$

TNTs: titania nanotubes

tVOCs: total volatile organic compounds

UV: ultraviolet

UVA: ultraviolet A (wavelength $400-315 \mathrm{~nm}$ )

VOCs: volatile organic compounds

\section{CONFLICT OF INTEREST}

There is no conflict of interest regarding this manuscript.

\section{AUTHOR CONTRIBUTION}

Nguyen Nhat Huy outline the research, plan the experiment, prepare the figures, prepare and complete the manuscript. Nguyen Thi Bich Ha and Dinh Pham Ngoc Huyen do the experiment, collect, and compose data. Hoang Cong Anh Duy and Lam Pham Thanh Hien support to do experiment and prepare equipment. Vo Thi Thanh Thuy and Nguyen Thi Thuy support to process data and prepare the draft manuscript.

\section{REFERENCES}

1. Strickman D, Frances SP, Debboun M. Prevention of bug bites, stings, and disease: Oxford University Press. 2009;Available from: https://doi.org/10.1093/acprof:oso/9780195365771. 001.0001.

2. Liu W, Zhang J, Hashim JH, Jalaludin J, Hashim Z, Goldstein BD. Mosquito coil emissions and health implications. Environmental health perspectives. 2003;111(12):1454-1460. PMID: 12948883. Available from: https://doi.org/10.1289/ehp.6286.

3. Endo O, Koyano M, Mineki S, Goto S, Tanabe K, Yajima $\mathrm{H}$, et al. Estimation of indoor air PAH concentration increases by cigarette, incense-stick, and mosquito-repellent-incense smoke. Polycyclic Aromatic Compounds. 2000;21(1-4):261-272. Available from: https://doi.org/10.1080/10406630008028538.

4. Koo LC, Ho JHC. Mosquito coil smoke and respiratory health among Hong Kong Chinese: results of three epidemiological studies. Indoor Environment. 1994;3(5):304-310. Available from: https://doi.org/10.1177/1420326X9400300510.

5. Salvi D, Limaye S, Muralidharan V, Londhe J, Madas S, Juvekar $\mathrm{S}$, et al. Indoor particulate matter $<2.5 \mu \mathrm{m}$ in mean aerodynamic diameter and carbon monoxide levels during the burning of mosquito coils and their association with respiratory health. Chest. 2016;149(2):459-466. PMID: 26158857. Available from: https://doi.org/10.1378/chest.14-2554.

6. Balakrishnan K, Mehta S, Kumar P, Ramaswamy P, Sambandam S, Kumar KS, et al. Indoor air pollution associated with household fuel use in India: an exposure assessment and modeling exercise in rural districts of Andhra Pradesh, India. Washington, DC. World Bank. 2004;

7. Lasek J, Yu YH, Wu JC. Removal of NOx by photocatalytic processes. Journal of Photochemistry and Photobiology C: Photochemistry Reviews. 2013;14:29-52. Available from: https: //doi.org/10.1016/j.jphotochemrev.2012.08.002.

8. Wang S, Ang H, Tade MO. Volatile organic compounds in indoor environment and photocatalytic oxidation: state of the art. Environ Int. 2007;33(5):694-705. PMID: 17376530. Available from: https://doi.org/10.1016/j.envint.2007.02.011.

9. Mo J, Zhang Y, Xu Q, Lamson JJ, Zhao R. Photocatalytic purification of volatile organic compounds in indoor air: A literature review. Atmos Environ. 2009;43(14):2229-2246. Available from: https://doi.org/10.1016/j.atmosenv.2009.01.034.

10. Sun Y, Zwolińska E, Chmielewski AG. Abatement technologies for high concentrations of NOx and $\mathrm{SO} 2$ removal from exhaust gases: A review. Critical Reviews in Environmental Science and Technology. 2016;46(2):119-142. Available from: https: //doi.org/10.1080/10643389.2015.1063334. 
11. Peral J, Domènech $X$, Ollis DF. Heterogeneous photocatalysis for purification, decontamination and deodorization of air. Journal of Chemical Technology \& Biotechnology: International Research in Process, Environmental AND Clean Technology. 1997;70(2):117-140. Available from: https://doi.org/10.1002/(SICI)1097-4660(199710) 70:2<117::AID-JCTB746>3.0.CO;2-F.

12. Pant HR, Pant B, Sharma RK, Amarjargal A, Kim HJ, Park $\mathrm{CH}$, et al. Antibacterial and photocatalytic properties of $\mathrm{Ag} / \mathrm{TiO} 2 / \mathrm{ZnO}$ nano-flowers prepared by facile one-pot hydrothermal process. Ceramics International. 2013;39(2):15031510. Available from: https://doi.org/10.1016/j.ceramint.2012. 07.097.

13. Ou HH, Lo SL. Review of titania nanotubes synthesized via the hydrothermal treatment: Fabrication, modification, and application. Sep Purif Technol. 2007;58(1):179-191. Available from: https://doi.org/10.1016/j.seppur.2007.07.017.

14. Wong CL, Tan YN, Mohamed AR. A review on the formation of titania nanotube photocatalysts by hydrothermal treatment. J Environ Manage. 2011;92(7):1669-1680. PMID: 21450395. Available from: https://doi.org/10.1016/j.jenvman.2011.03.006.

15. Liu N, Chen X, Zhang J, Schwank JW. A review on TiO2-based nanotubes synthesized via hydrothermal method: Formation mechanism, structure modification, and photocatalytic ap- plications. Catal Today, 2014:225(0):34-51. Available from: https://doi.org/10.1016/j.cattod.2013.10.090.

16. Nguyen $\mathrm{NH}$, Bai H. Photocatalytic removal of $\mathrm{NO}$ and NO2 using titania nanotubes synthesized by hydrothermal method. J Environ Sci. 2014;26(5):1180-1187. Available from: https: //doi.org/10.1016/S1001-0742(13)60544-6.

17. Nguyen $\mathrm{NH}, \mathrm{Wu} \mathrm{HY}$, Bai $\mathrm{H}$. Photocatalytic reduction of $\mathrm{NO} 2$ and $\mathrm{CO} 2$ using molybdenum-doped titania nanotubes. Chem Eng J. 2015;269(0):60-66. Available from: https://doi.org/10 1016/j.cej.2015.01.099.

18. Luengas A, Barona A, Hort C, Gallastegui G, Platel V, Elias A. A review of indoor air treatment technologies. Reviews in Environmental Science and Bio/Technology. 2015;14(3):499-522. Available from: https://doi.org/10.1007/s11157-015-9363-9.

19. Jiang F, Zheng S, An L, Chen H. Effect of calcination temperature on the adsorption and photocatalytic activity of hydrothermally synthesized TiO2 nanotubes. Appl Surf Sci. 2012;258(18):7188-7194. Available from: https://doi.org/10 1016/j.apsusc.2012.04.032.

20. Yu J, Yu H, Cheng B, Trapalis C. Effects of calcination temperature on the microstructures and photocatalytic activity of titanate nanotubes. J Mol Catal A: Chem. 2006;249(1-2):135142. Available from: https://doi.org/10.1016/j.molcata.2006.01 003. 


\title{
Nghiên cứu xử lý các hợp chất hữu cơ bay hơi từ quá trình đốt nhang muỗi bằng phương pháp quang xúc tác
}

\author{
Nguyễn Nhật Huy 1,2,* ${ }^{*}$ Nguyễn Thị Bích Hà ${ }^{1,2}$, Đinh Phạm Ngọc Huyền ${ }^{1,2}$, Võ Thị Thanh Thùy ${ }^{1,2}$, \\ Hoàng Công Anh Duy 1,2, Lâm Phạm Thanh Hiền ${ }^{1,2}$, Nguyễn Thị Thủy ${ }^{3}$
}

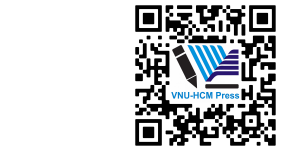

Use your smartphone to scan this QR code and download this article

${ }^{1}$ Khoa Môi truơơng và Tài Nguyên, Truờng Đại học Bách Khoa TP.HCM, 268 Lý Thường Kiệt, Phường 14, Quận 10, TP.HCM

${ }^{2}$ Đai học Quốc gia Thành phố Hồ Chí Minh, Phường Linh Trung, Quận Thủ Đuic, TP.HCM

${ }^{3}$ Khoa Môi trường - Tài nguyên và Biến đổi Khí hậu, Truiờng Đai học Công nghiệp Thực phâm TP.HCM, 140 Lê Trọng Tấn, Phường Tây Thạn, Quận Tân Phú, TP.HCM

Liên hệ

Nguyễn Nhật Huy, Khoa Môi trường và Tài Nguyên, Trường Đại học Bách Khoa TP.HCM, 268 Lý Thường Kiệt, Phường 14, Quận 10, TP.HCM

Đại học Quốc gia Thành phố Hồ Chí Minh, Phường Linh Trung, Quận Thủ Đức, TP.HCM

Email:nnhuy@hcmut.edu.vn

Lịch sử

- Ngày nhận: 29/08/2019

- Ngày chấp nhận: 4/04/2020

- Ngày đăng: 30/6/2020

DOI : 10.32508/stdjsee.v4i1.509

Check for updates

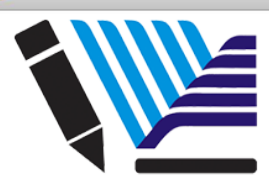

VNU-HCM Press
TÓM TẮT

Nhang muỗi là một sản phẩm được sử dụng rộng rãi, tuy chất lượng nhang muỗi đã được quản lý nhưng khói nhang muỗi vẫn có thể có những tác động nhất định đến sức khỏe người dùng trên thực tế. Nghiên cứu này tiến hành khảo sát nồng độ các hợp chất hữu cơ dễ bay hơi (tVOCs) có trong khói nhang muỗi và thực nghiệm xử lý khí ô nhiễm bằng phương pháp quang xúc tác. Một khảo sát trực tuyến sử dụng công cụ Google form đã được thực hiện để chọn ra ba loại nhang muỗi được sử dụng nhiêu nhất ở Việt Nam (MOSFLY, RAID và JUMBO VAPE) cũng như mức độ và điều kiện sử dung. Cả ba loại nhang muỗi này được thí nghiệm đốt trong một phòng bình thường trong 8 giờ để xác định mức độ ô nhiễm không khí. Kết quả cho thấy một trong ba loại nhang phát thải tVOCs cao đến 1621 ppb, cao nhất trong ba loai nhang sử dung. Loai nhang này sau đó được dùng làm nguồn phát thải VOCs để thử nghiệm khả năng xử lý của một thiết bị quang xúc tác trong buônng kín. Kết quả xử lý chất ô nhiễm VOCs từ khói nhang bằng thiết bị xử lý quang xúc tác cho thấy $\mathrm{TiO}_{2}$ dang ống (titania nanotubes, TNTs) biến tính với kim loại và xử lý nhiệt cho hiệu quả xử lý cao, đạt tiêu chuẩn không khí trong nhà của Trung Quốc ( $\leq 490$ ppb) sau 180 phút xử lý với nồng độ đâu vào trong khoảng 1600 ppb. Việc thay đổi các điều kiện biến tính TNTs và điêu kiện vận hành cho thấy hiệu quả xử lý cao nhất đạt được với xúc tác TNTs tẩm $\mathrm{Zn}\left(\mathrm{NO}_{3}\right)_{2} \cdot 6 \mathrm{H}_{2} \mathrm{O}$ với tỉ lệ mol $\mathrm{Zn} / \mathrm{Ti}$ là 0,5\%, nung ở $500^{\circ} \mathrm{C}$, và khối lượng $2 \mathrm{~g}$ thì thiết bị quang xúc tác cho thời gian xư lý đạt tiêu chuẩn ngắn nhất. Kết quả từ nghiên cứu này chỉ ra rằng việc đốt nhang muỗi trong nhà gây ô nhiễm không khí có thể ảnh hưởng đến sức khỏe con người và quang xúc tác là một công nghệ tiềm năng để xử lý VOCs từ việc đốt nhang muỗi trong nhà.

Từ khoá: Nhang trừ muỗi, tVOCs, ô nhiễm không khí trong nhà, quang xúc tác

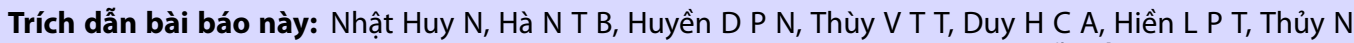
T. Nghiên cứu xử lý các hợp chất hữu cơ bay hơi từ quá trình đốt nhang muỗi bằng phương pháp quang xúc tác. Sci. Tech. Dev. J. - Sci. Earth Environ.; 4(1):162-169. 